С.В. Шпіт, Н.В. Мирнінко, А.В. Мойсеєнко, А.В. Какотко, P.О. Сгоров

\title{
СИГНАЛЬНО-ПАРАМЕТРИЧНИЙ МЕТОД ПОБУДОВИ РОБАСТНИХ СИСТЕМ КЕРУВАННЯ
}

Анотація: робота присвячена використанню методів, що базуються на робастному підході при побудові систем з нечітко визначеними математичними моделями та неповною апріорною інформацією.

Ключові слова: адаптація, невизначеність робастність, еталонна модель, контур само налаштування, передаточна функція, міра якості.

\section{Постановка задачі}

Як відомо [5], що параметричне налаштування коефіціентів $k_{i}$ передаточної функції $W\left(s, k_{i}\right)$ з невизначеними параметрами може здійснюватися на основі застосування відповідної еталонної моделі $W_{m}(s)$ та контуру само налаштування $\mathrm{KCH}$, який працюе на основі вимірювання сигналу разузгодження $E(t)=Y_{m}(t)-Y\left(t, k_{i}\right)$ з використанням міри якості у вигляді $J=F(E)=E^{2}(t)$. Чутливість міри якості відносно невизначеного параметра, тобто $\frac{\partial J}{\partial k_{i}}$ визначає класичний алгоритм роботи $\mathrm{KCH}$

$$
\begin{aligned}
\frac{\partial J}{\partial k_{i}}=\frac{\partial F(E)}{\partial E} \cdot \frac{d E}{d k_{i}}=2 E & \cdot \frac{d\left(Y_{m}(t)-Y\left(t, k_{i}\right)\right)}{d k_{i}}= \\
& =2 E \cdot \frac{d W\left(p, k_{i}\right)}{d k_{i}} \cdot g(t)=2 E \cdot u_{i}(t) \cdot g(t),
\end{aligned}
$$

де $u_{i}(t)$ - чутливість передаточної функції $W\left(s, k_{i}\right)$ по параметру $k_{i}$. Недоліки такого алгоритму стають очевидні якщо представити $W\left(s, k_{i}\right)=\frac{k_{i}}{s}$ (рис. 1) процес налаштування стає коливальним.
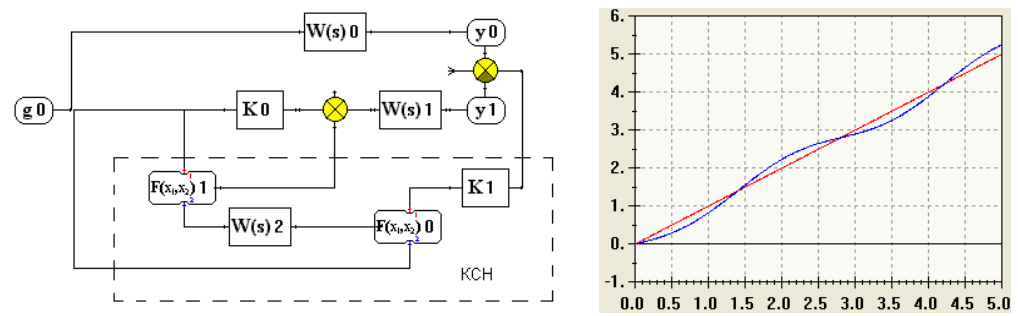

Рис. 1 - Приклад роботи класичного КСН: $W(s) 1=s^{-1}, k 0=k_{i}$ , $W(s) 0=k s^{-1}, k 1=2, W(s) 2=\lambda s^{-1}, W\left(x_{1}, x_{2}\right) 1$ та $W\left(x_{1}, x_{2}\right) 2-$ пристрої добутку.

Ці недоліки можна виключити якщо додати в алгоритм параметричного КСН похідну від сигналу похибки $E(t)$ (Рисунок 2), де 

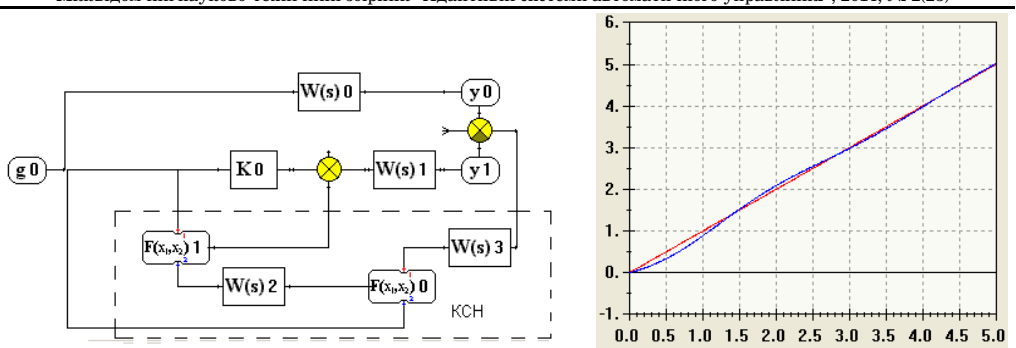

Рис. 2 - Процес адаптації при модернізованому КСН

$k 1=W(s) 3=\frac{q_{1} \tau+q_{0}}{0.01 s+1}$. Це дає можливість значно прискорити процес адаптації параметрів системи до заданих значень.

Аналіз застосування параметричного алгоритму адаптації розглянемо на прикладі системи другого порядку, яка повинна забезпечувати заданий рух $y 1(t)$ при значних збудженнях коефіціентів підсилення та постійних часу і дії неконтрольованих завад $y 0(t)$ (рис. 3). Будемо вважати що заданий рух задається не збудженою (еталонною) моделлю $W_{m}(s)=\frac{W(s) 5 \cdot W(s) 6}{1+W(s) 5 \cdot W(s) 6 \cdot k 1}$, яка забезпечуе нульову похибку у статичному режимі. На реальну систему із параметрично невизначеною $W_{m}(s)=\frac{W(s) 5 \cdot W(s) 6}{1+W(s) 5 \cdot W(s) 6 \cdot k 1}$ передаточною функцією у момент часу $t 1$ починає діяти сигнальна невизначеність $Y 0(t)$.

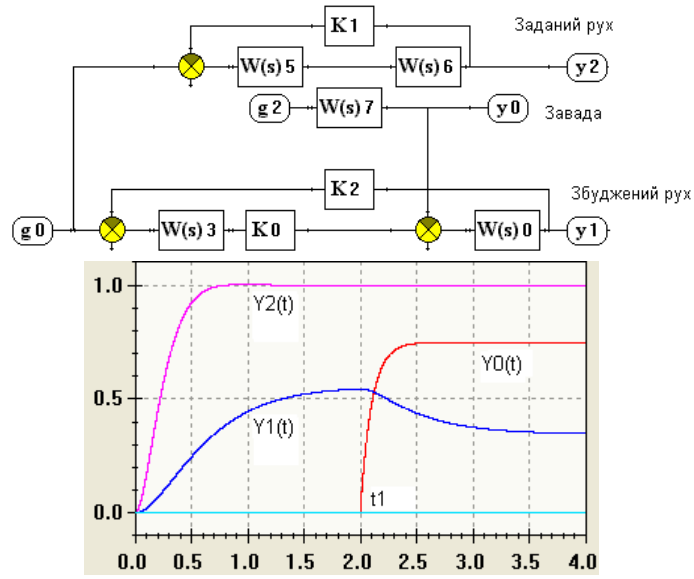

Рис. 3 - Перехідні процеси в системі 2-го порядку при дії $g 0(t)=1(t)$

Якщо для адаптації ввести в систему параметричний канал КСН (Рис. 4, В1 вкл.1, В2 вим.), то повної компенсації невизначеpas, 2014

(c) С.В. Шпіт, Н.В. Мирнінко, А.В. Мойсеєнко, А.В. Какотко, Р.О. Єго- 
ностей по коефіцієнту підсилення не спостерігається (Рис. 4a). Крім того відомо які труднощі виникають при побудові параметричних КСН для адаптації постійних часу об’ктів керування. Також слід зауважити, що при застосуванні параметричних методів адаптації потребує знання структури відповідної передаточної фрнкції або так званих допоміжних операторів.

Застосування класичних методів сигнальної адаптації з еталонною моделлю [4], а також методів сигнальної адаптації з дуальним спостерігачем [6,7], які дають більш точні загальні процеси адаптації (Рисунок. 4б), потребують значних коефіцієнтів підсилення, що ускладнює задачу забезпечення загальної стійкості системи керування. Слід зауважити, що сигнальний метод адаптації не потребує побудови контурів налаштування по кожному збудженому параметру та краще компенсує дію не контрольованих зовнішніх збуджень. На основі аналізу одного та другого методів побудови адаптивної системи керування було запропоновано застосувати сигнально- параметричний метод, при якому невизначені коефіцієнти підсилення компенсуються на основі параметричних методів, а загальна адаптація уточнюеться методами адаптації із застосуванням дуального спостерігача.

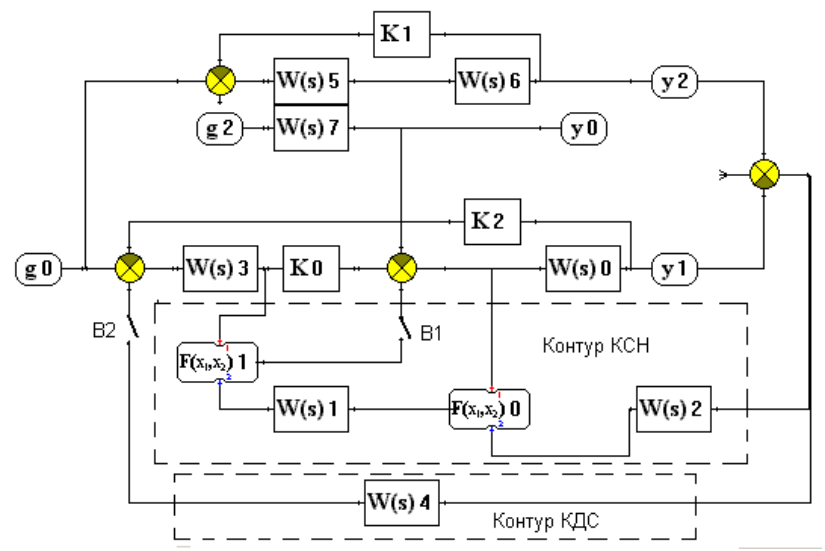

Рис. 4 - Структурна схема робастної системи з сигнально - параметричним методом компенсації невизначеностей

Експериментальні дослідження виконувалися на програмномоделюючому комплексі “SHS-TAK", розробленому на кафедрі Технічної кібернетики НТУУ “КПІ" під керівництвом доцента Шпіт C.B.

\section{Висновки}

Результати аналізу запропонованого сигнально-параметричного методу побудови адаптивної системи керування при великих рі- 

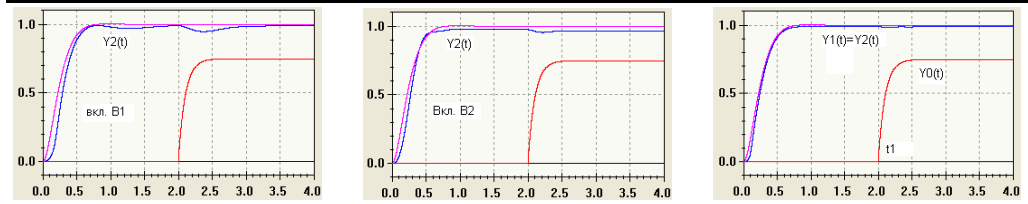

Рис. 5 - Перехідні процеси: а - параметричний КСН (В1 вкл. В2вим.), б - сигнальний ЛСД ( В2 вкл. В1вим.), в - сигнальнопараметричний ( В2 вкл.В1вкл.)

зноманітних невизначеностях як у передаточних фрункціях, так і при дії неконтрольованих сигнальних збудженнях (Рисунок 4в, Рисунок 5б)
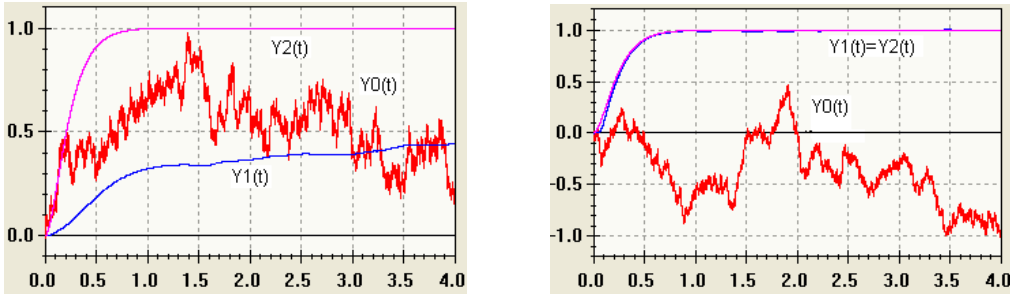

Рис. 6 - Результати дослідження адаптивної системи при дії випадкової завади (а - канали компенсації виключено, б - канали компенсаціє включено)

Запропонований метод побудови адаптивної системи дозволяе застосовувати еталонну модель, яка визначаеться передаточною функцією, визначеною на основі заданих показників якості та цілі керування (наприклад, на основі функціоналів Ньютона або Баттерворта)

\section{Список використаних джерел}

1. Принцип инвариантности и условия его применения при расчете линейных и нелинейных систем/ Петров Б.Н.// Труды I Конгресса ИФАК, т. 1, 1960.

2. Оптимальні і адаптивні системи автоматичного керування: Навчальний посібник/ Тютюнник А.Г.// Житомир: ЖITI, 1998. $-512 \mathrm{c}$.

3. Системи автоматичного керування 3 еталоном - спостерігачем / Шпіт С.В., Янцеловський С.Г., Ткаченко О.I.//Адаптивнісистеми автоматичного управління. 2008-№12(32).- с. 145 - 151.

4. Автономна багатомірна система керування з еталонами - спостерігачами / Шпіт С.В., Семчишин А.В.// Адаптивнісистеми автоматичного управління. -2009 - №13(33).- с. . 
5. Дуальнийспостерігач в системах автоматичного керування / Шпіт С.В.// Адаптивнісистеми автоматичного управління. 2009 - №14(34).- с. .

6. Дослідження систем керування при неповній апріорній інформації / Шпіт С.В. //Адаптивнісистеми автоматичного управління. -2012 - №21(40).- с. .

7. Дуальний спостерігач як компенсатор неконтрольованих збурень / Шпіт С.В.// Адаптивнісистеми автоматичного управління. -2012 - №20(40).- с. .

Отримано 11.09.2014 p. 